Reprod. Nutr. Dévelop., 1987, 27 (1 A), 89-94.

\title{
Semen characteristics in furazolidone-treated goats
}

\author{
A. I. MUSTAFA, B. H. ALI, T. HASSAN
}

Department of Medecine, Pharmacology and Toxicology, Faculty of Veterinary Science,

P.O. Box 32, Khartoum North, Sudan.

Summary. Furazolidone was given to male Nubian goats for 5 days at a therapeutic dose of $10 \mathrm{mg} / \mathrm{kg}$ or at a dose of $40 \mathrm{mg} / \mathrm{kg}$, and the effect on semen morphology and biochemistry was studied. At the lower dose, furazolidone significantly reduced seminal ejaculate volume, the number of motile spermatozoa per ejaculate and the number of live spermatozoa per ejaculate, while secondary abnormalities increased. At a dose of $40 \mathrm{mg} / \mathrm{kg}$, the same effects were produced and there were significant reductions in wave motion, percentage of motile spermatozoa and percentage of live spermatozoa. Fructose concentration was significantly reduced with both the doses, while citric acid was not affected by either one. Alkaline phosphatase activity was lower with $10 \mathrm{mg} / \mathrm{kg}$ of furazolidone and increased when the larger dose was administered.

\section{Introduction.}

The nitrofuran drug, furazolidone (N-5-nitro-2-furfurylidene-amino-2oxazolidine), is used to treat certain microbial diseases in humans (Dupont et al., 1984 ; Zhi-Tian et al., 1985) and animals (Brander, Pugh and Bywater, 1982) and as an additive in pig and poultry feeds. It has a number of pharmacological and toxicological properties (for review, see Ali, 1983).

The anti-fertility effect of some nitrofuran drugs (e.g. nitrofurazone, furalatdone and nitrofurantoin) has been well-documented in humans and animals (Nelson and Bunge 1957; Albert et al., 1974; Yunda and Kushniurk 1974; Hagenas et al., 1978). Furazolidone has been reported to have some adverse effects on the fertility of male chickens (Cooper and Skulski, 1956 ; Ali et al., 1984). However, the effect of this drug on mammal fertility has not been studied thoroughly (Koeda et al., 1976), and there are no reports of its effect on the reproduction of domestic animals, except for our recent work on the effect of furazolidone on reproductive hormone of the female goat (Hassan et al., 1986).

The aim of the present work was to determine the effect of furazolidone on the fertility of male goats by assessing the morphological and biochemical properties of their semen.

\section{Materials and methods.}

Animals. - Healthy male Nubian goats, aged 2 to 4 years and weighing 16 to $19 \mathrm{~kg}$, were used. They were housed in groups and given lucerne, sorghum grains 
and water ad libitum. Before the start of the experiment, the animals were acclimatized for one month and trained for semen collection by electro-ejaculation on four occasions.

Treatment. - For 5 days, the experimental goats were given one of two doses of pure furazolidone (Orphahell, The Netherlands) suspended in distilled water : a therapeutic dose of $10 \mathrm{mg} / \mathrm{kg}$ or a dose of $40 \mathrm{mg} / \mathrm{kg}$. The semen was collected on the 6th day.

Semen collection. - Before semen collection, faeces were removed from the bucks by warm saline enema to ensure adequate contact between the rectal mucosa and the ejaculatory probe. The animal was laid on its side and a transistorized rectal probe (The Ruakura, MK IV Ram Probe, Alfred Cox, Surrey, England) was lubricated with glycerine and inserted approximately $11.5 \mathrm{~cm}$ into the rectum. The probe was positioned so that the electrodes were oriented ventrally to press the ring electrodes against the rectal wall in the region of the semina vesicle, prostate gland and hypogastric plexus. A total of 15 stimuli were given to obtain semen emissions in graduated tubes. The semen was immediately taken to the laboratory for evaluation.

Morphological evaluation of semen. - The volume, wave motion, percentage of motile spermatozoa, sperm count, total spermatozoa per ejaculate, number of motile spermatozoa per ejaculate and the proportions of primary and secondary abnormalities in the semen samples were evaluated by standard methods described by Campbell et al. (1956) and Zemjanis (1969).

Biochemical evaluation of semen. - The concentration of fructose was estimated colorimetrically by the method of Roe (1934) modified by Mann (1964). Citric acid concentration was determined by the colorimetric method of Speck et al. (1946) modified by Mann et al. (1957) and Linder and Mann (1960). The activity of alkaline phosphatase (AP) was estimated spectrophotometrically according to the Sigma Technical Bulletin, No. 246 (1982).

Statistical analysis. - The values reported were the means \pm SEM with the number of animals in parenthesis. The means of the different experimental groups were compared using Student's t-test.

\section{Results.}

Effect of furazolidone on semen morphology. - The effect of furazolidone treatment on various morphological parameters of semen is shown in table 1. At a dose of $10 \mathrm{mg} / \mathrm{kg}$, the drug decreased significantly ejaculate volume, the number of motile spermatozoa per ejaculate and the number of live spermatozoa per ejaculate. Secondary abnormalities also increased significantly. When the goats were given $40 \mathrm{mg} / \mathrm{kg}$, the effects were similar and significant reductions in wave 
motion, percentage of motile spermatozoa and percentage of live spermatozoa were obtained.

TABLE 1

The effect of oral administration of furazolidone (FZ) on some semen characteristics of Nubian goats.

\begin{tabular}{|c|c|c|c|}
\hline Parameter & Control & $\mathrm{FZ}(10 \mathrm{mg} / \mathrm{kg})^{1}$ & $\mathrm{FZ}(40 \mathrm{mg} / \mathrm{kg})^{1}$ \\
\hline $\begin{array}{c}\text { Ejaculate volume } \\
\text { (ml) }\end{array}$ & $05+0.12(10)$ & & $0.70+0.10(4)^{*}$ \\
\hline Wave motion & & & \\
\hline$(0-5)$ & $4.5 \pm 0.31(10)$ & $4.13 \pm 0.31(8)$ & $2.63 \pm 0.38(4)^{* * *}$ \\
\hline $\begin{array}{c}\text { Motile spermatozoa } \\
(\%)\end{array}$ & $89.40 \pm 2.55(10)$ & $80.00+$ & $51.25+13.90(4)^{*}$ \\
\hline Motile spermatozoa/ejaculate & & & \\
\hline $\begin{array}{c}\left(\times 10^{9}\right) \\
\text { Total spermatoz }\end{array}$ & $1.66 \pm 0.37(10)$ & $0.74 \pm 0.22(8)^{*}$ & $1.13 \pm 0.36(4)$ \\
\hline$\left(\times 10^{9}\right)$ & $1.86 \pm 0.39(10)$ & $0.92 \pm 0.23(8)$ & $2.21 \pm 0.68(4\}$ \\
\hline $\begin{array}{l}\text { Sperm count } \\
\qquad\left(\times 10^{9} / \mathrm{ml}\right)\end{array}$ & $1.77 \pm 0.25(10)$ & $1.53 \pm 0.24(8)$ & $3.15 \pm 0.68(4)$ \\
\hline $\begin{array}{l}\text { Live spermatozoa } \\
(\%)\end{array}$ & $86.30 \pm 2.57(10)$ & $71.88 \pm 8.41(8)$ & $64.75 \pm 4.39(4)^{* * *}$ \\
\hline $\begin{array}{l}\text { Live spermatozoa/ejaculate } \\
\qquad\left(\times 10^{9}\right) \\
\text { Primary abnormalities }\end{array}$ & $1.61 \pm 0.36(10)$ & $0.66 \pm 0.24(8)^{*}$ & $1.43 \pm 0.47(4)$ \\
\hline $\begin{array}{c}(\%) \\
\text { Secondary abnormalities }{ }^{4}\end{array}$ & $6.70 \pm 0.54(10)$ & $5.50 \pm 0.60(8)$ & $5.75 \pm 0.95(4)$ \\
\hline (\%) & $15.30 \pm 1.82(10)$ & $25.38 \pm 3.59(8)^{*}$ & $33.00 \pm 4.56(4)^{* *}$ \\
\hline
\end{tabular}

Values reported are means \pm s.e.m. (number of animals).

1 Doses were given for five days, and samples collected on the 6 th day.

$2 * \mathrm{P}<0.05 ;{ }^{*} \mathrm{P}<0.01 ; * *{ }^{*} \mathrm{P}<0.001$, compared with the control.

3 Primary abnormalities include the following: Head (all types of deviation in form and size) ; Middle piece (aboxial attachement, double middle piece, coiled middle piece, frayed, thin middle piece) ; Tail (coiled tail).

4 Secondary abnormalities include the following : loose normal heads; detachment of gilea capitis, sperm cells with proximal droplets ; sperm cells with curved middle piece ; sperm cells with bent, looped or detached tails.

Effect of furazolidone on semen biochemistry. - Table 2 shows the effect of the drug on seminal concentrations of fructose, citric acid and AP activity. Fructose concentration decreased significantly with both doses. A dose of

\section{TABLE 2}

The effect of oral administration of furazolidone (FZ) on some semen characteristics of Nubian goats.

\begin{tabular}{lccc}
\hline & Control & $F Z(10 \mathrm{mg} / \mathrm{kg})^{2}$ & $\mathrm{FZ}(40 \mathrm{mg} / \mathrm{kg})^{2}$ \\
\hline $\begin{array}{c}\text { Fructose concentration } \\
(\mathrm{mg} / 100 \mathrm{ml})\end{array}$ & $213.56 \pm 35.69(8)^{1}$ & $66.26 \pm 14.42(6)^{* * 3}$ & $44.26 \pm 6.60(6)^{* * *}$ \\
$\begin{array}{c}\text { Citric acid concentration } \\
(\mathrm{mg} / 100 \mathrm{ml})\end{array}$ & $68.80 \pm 12.19(10)$ & $60.86 \pm 10.35(7)$ & $55.60 \pm 13.92(5)$ \\
$\begin{array}{c}\text { Alkaline phosphatase } \\
\text { activity }(\mathrm{U} / \mathrm{ml})\end{array}$ & $21.81 \pm 1.65(6)$ & $9.48 \pm 1.69(6)^{* * *}$ & $45.61 \pm 2.03(6)^{* * *}$ \\
\hline
\end{tabular}

\footnotetext{
${ }^{1}$ Data expressed as mean \pm s.e.m.

$2 \mathrm{FZ}$ was given for five days and samples collected on the 6 th day.

$3{ }^{*} \mathrm{P}<0.05 ;{ }^{* *} \mathrm{P}<0.01$, ${ }^{* *} \mathrm{P}<0.001$, compared with controls.
} 
$10 \mathrm{mg} / \mathrm{kg}$ significantly reduced AP activity, while $40 \mathrm{mg} / \mathrm{kg}$ caused a significant increase $(P<0.001)$. Citric acid concentration was not affected by either dose $(P<0.1)$.

\section{Discussion.}

The present results show that furazolidone treatment at doses of 10 or $40 \mathrm{mg} / \mathrm{kg}$ had a deleterious effect on semen quantity and quality. The decrease in seminal volume observed could have resulted from a decrease in seminal plasma - the latter constitutes the bulk of whole semen - but number of the total spermatozoa per ejaculate was not significantly altered by the treatment. Therefore, the decrease in semen quantity might reflect the influence of the drug on the secretory activity of male accessory glands.

The significant decrease in the number of motile and live spermatozoa per ejaculate in goats treated with furazolidone probably resulted from the significant decreases in ejaculate volume and sperm concentration (sperm count/1). At small doses in vitro, the nitrofurans are known to be sperm-immobilizing agents (Albert et al., 1974). In the present work, furazolidone appears to reduce sperm motility in vivo, indicating that at least some of the drug, or its metabolites, passed into the semen.

The increase in sperm abnormalities exceeds the normal 20 percent usually found in semen (Foote and Trimberger, 1968). Thus, a decrease in fertilizing ability would be expected in goats treated with this drug. At $40 \mathrm{mg} / \mathrm{kg}$, furazolidone produced significant reductions in wave motion and the percentage of motile and live spermatozoa. It is established that a decrease in sperm motility affects fertility adversely since high motility enables a large number of spermatozoa to reach the cervix, penetrate into its mucosal folds and then be distributed throughout the uterus and Fallopian tubes (Lightfoote and Salamon, 1970 ; Lightfoote and Restall, 1971). There is a fairly good correlation between sperm motility and fertilizing ability (White, 1968). The marked reduction in sperm motility of furazolidonetreated goats and the decrease in the number of live spermatozoa possibly occurred as a result of alterations in the metabolism of the testes and/or spermatozoa. It is known that nitrofurans considerably alter testis metabolism, inhibiting both the utilization of glucose and the formation of citric acid by gonadal tissue, and altering pyruvic acid metabolism (Paul et al., 1952 ; 1953 ; 1954 ; Featherstone et al., 1955).

Semen fructose concentration was significantly decreased by both the doses used. This finding could be ascribed to disturbed testis metabolism and the inhibition of glucose utilization (Paul et al., 1952 ; Featherstone et al., 1955). It is known that when blood glucose is converted into seminal fructose, a series of enzymatic reactions occurs, leading to the formation of 6-phosphofructose, which is finally converted by alkaline phosphatase into seminal fructose (Mann, 1964).

A more detailed study of the effects of chronic administration of smaller doses of furazolidone on the reproductive functions of goats, and of their reversibility, may be warranted. The male hormone profiles of goats treated with furazolidone are now being measured in our laboratory; the results may help to eluci- 
date the actions of this drug on the goat reproductive system. It would also be of interest to measure the concentrations of the drug in the semen of treated animals.

Reçu en octobre 1986.

Accepté en novembre 1986.

Acknowledgements. - This work was supported by the Graduate College, University of Khartoum. The furazolidone was a gift of Orphahell, The Netherlands. Thanks are due to Mr. M. Kheir who cared for the animals.

Résumé. Caractéristiques du sperme de boucs traités à la furazolidone.

De la furazolidone est administrée à des boucs pendant 5 jours, à la dose de $10 \mathrm{mg} / \mathrm{kg}$ (dose thérapeutique) ou de $40 \mathrm{mg} / \mathrm{kg}$. L'effet de la drogue sur les caractéristiques morphologiques et certaines propriétés biochimiques du sperme est examiné. A la plus faible dose, la furazolidone réduit significativement le volume de l'éjaculat ainsi que le nombre de spermatozoïdes mobiles et de spermatozoïdes vivants. La proportion d'anomalies secondaires est aussi augmentée. A forte dose, les mêmes troubles sont observés, mais avec une sévérité accrue. La concentration en fructose est réduite, quelle que soit la dose de furazolidone, tandis que celle de l'acide citrique $n^{\prime}$ est pas modifiée. L'activité de la phosphatase alcaline est réduite par les faibles doses et stimulée par les fortes doses de furazolidone.

\section{References}

ALBERT P. S., MINIBERG D. T., DAVIS J. E., 1974. Nitrofurans : Sperm immobilizing agents. Their tissue toxicity and clinical application. Urology, 4, 307-310.

ALI B. H., 1983. Some pharmacological and toxicological properties of furazolidone. Vet. res. Comm., 6, 1-11.

ALI B. H., HOMEIDA A. M., KNIFTON A., 1984. The effect of furazolidone on fertility of male chickens. Comp. biochem. Physiol., 78 C, 43-47.

BRANDER G. C., PUGH D. M., BYWATER R. J., 1982. Veterinary applied pharmacology and therapeutics, 4th ed., London, Bailliere Tindall, p. 432.

CAMPBElL R. C., DOTT H. M., GLOVER T. D., 1956. Nigrosin-eosin as a stain for differentiating live and dead spermatozoa. J. agr. Sci., Camb., 48, 1-8.

COOPER D. M., SKULSKI G., 1956. Effect of feeding furazolidone to fowls. Effect on body weight and sexual development in cockerels. J. comp. path. Therap., 66, 299-311.

DUPONT H., ERICSSON C. D., GALINDO E., WOOD L. V., MORGEN D., BITSURA J. A. M., Mendiola J. G., 1984. Furazolidone versus ampicillin in the treatment of Traveler's diarrhea. Antimicro. Agents Chemotherap., 26, 160-163.

FEATHERSTONE R. M., NELSON W. O., WELDEN F., MERBERGER E., BOCCABELLA A., BOCABELLA R., 1955. Pyruvate oxidation in testicular tissues during furadroxyl-induced spermatogenic arrest. Endocrinology, 56, 727-736.

FOOTE R. H., TRIMBERGER G. M., 1968. Artificial insemination, 135-153. In HAFEZ E.S.E., Reproduction in farm animals, 2nd ed., Phaladelphia, Lea and Febiger.

HAGENAS L., POLEN L., RITZEN E. M., 1978. The effect of nitrofurazone on the endocrine secretory and spermatogenic function of the rat testis. Andrologia, 10, 107-126.

HASSAN T., HOMEIDA A. M., ALI B. H., 1986. Effects of furazolidone on some reproductive hormones during oestrous cycle in the goat. Comp. Biochem. Physiol, 85C, 255-257.

KOEDA T., SASAKI N., KOHANAWA M., KONNO S., 1976. Acute toxicity of furazolidone for guinea pigs. Ann. Rep. nat. vet. Assay Lab. (Japan), 18, 13-32. 
LIGHTFOOTE R. J., SALAMON S., 1970. Fertility of ram spermatozoa frozen by the pellet method. 1. Transport and viability of spermatozoa within the genital tract of the ewe. J. Reprod. Fert., 22, 385-398.

LIGHTFOOTE R. J., RESTALL B. J., 1971. Effects of site of insemination, sperm motility and genital tract contraction on transport of spermatozoa in the ewe. J. Reprod. Fert., 26, 1-13.

LINDER H. R., MANN T., 1960. Relationship between the content of androgenic steroids in the testes and the secretory activity of the seminal vesicles in the bull. J. Endocrinol., 21, 341360.

MANN T., DAVIES D. V., HUMPHERY G. F., 1949. Fructose and citric acid assay in the secretions of the accessory glands of reproduction as indictar tests of male sex hormone activity. $J$. Endocrinol., 6, 75-85.

MANN T., 1954. The two components of semen: spermatozoa and seminal plasma, 1-29. In The biochemistry of semen Methuen and Co. Ltd., London, John Wiky and Sons Inc. N. Y.

MANN T., SHORT R. V., WALTON A., ARCHER R. K. and MILLER W. C., 1957. The " tail-end sample " of the stallion semen. J. agr. Sci., Camb., 49, 301-312.

MANN T., 1964. Fructose, polyols and organic acids, 237-264. In Biochemistry of semen and of the male reproductive tract, 1st ed., Methuen and Co. Ltd., London, John Wiley and Sons Inc., N. $Y$.

MANN T., 1969. Physiology of semen and of male reproductive tract, 277-312. In COLE H. H., CUPPS P. T., Reproduction in domestic animals, Acad. Press, N. Y. and London.

NELSON W. O., BUNGE R. G., 1957. Effect of therapeutic dosage of nitrofurantoin (Furadantin) upon spermatogenesis in man. J. Urology, $77,275-281$.

NISSIM J. A., 1957. Increased pituitary gonadotrophin activity after degeneration of semineferous tubules produced by nitrofurazone. Lancet, 1, 304-305.

PAUL H. E., PAUL M. F., KAPKO F., 1952. Effect of furacin (5-nitro-2-furaldehyde semicarbazone) on the in vitro metabolism of mammalian tissues. Proc. Soc. exp. Biol. Med., 79, 555-558.

PAUL H. E., PAUL M. F., KOPKO F., BENDER R. C., EVERETT G., 1953. Carbohydrate metabolism studies on the testes of rats fed certain nitrofurans. Endocrinology, 53, 585-592.

PAUL M. F., PAUL H. E., KOPKO F., BRYSON M. J., HARRINGTON C., 1954. Inhibition of furacin of citrate formation in testis preparation. J. biol. Chem., 206, 491-497.

ROE J. H., 1934. A colorimetric method for the determination of fructose in blood and urine. J. Biol. Chem., 107, 15-22.

SPECK J. F., MOULDER J. W.. EVANS Jr. F. A., 1946. The biochemistry of malaria parasite. V. Mechanism of pyruvate oxidation in the malaria parasite. J. biol. Chem., 64, 119-128.

WHITE I. G., 1968. Motility of the sperm, 189-202. In HAFEZ E.S.E., Reproduction in farm animals, 2nd edition, Philadelphia, Lea and Febiger, p. 189-202.

YUNDA I. F., KUSHNIURK I., 1974. Effect of nitrofuran preparation on spermatogenesis. Bull. exp. Biol. Med., 77, 534-536.

ZEMJANIS R., 1969. Semen examination, 497-510. In MIDWAY W., PRIER J. E., WILKINSON J. S., Textbook of veterinary clinical pathology. Williams and Wilkins Co., Baltimore.

ZHI-TIAN Z., ZHENG-YING W., CHU YA-YIAN, YI-NUNG L., WIONG-FANG L., SAN-REN L., ZHAO-MIN X., 1985. Double-blind short term trial of furazolidone in peptic ulcers. Lancet, 1 (8436), 1048-1049. 